\section{Effect of Auxin-Synergistic Preparation and Fertilization on Fruit Setting and Fruit Quality of Apple}

\author{
József Racskó \\ University of Debrecen, Centre for Agricultural Sciences, \\ Institute for Extension and Development, Debrecen \\ racsko@helios.date.hu
}

\section{SUMMARY}

On seven apple cultivars (Gala Must, Gloster, Granny Smith, Idared, Jonagold, Jonathan Csány and Mutsu), the author studied the influence of N-phenyl-phthalamic acid (Nevirol 60 WP) and fertilization on fruit setting and fruit quality.

The research results show that by using Nevirol 60 WP and applying fertilization, we can improve the fruit setting and number of fruit per tree. As a result of this process, the yield amount will increase.

Nevirol 60 WP has a great effect on the improvement of yield amount, especially by good nutrient supply. There is a significant difference between the reactions of different cultivars. The most sensitive to these treatments were the cultivar Gala Must and Granny Smith. Before using Nevirol 60 WP we have to take into consideration that the increased yield needs a higher nutrient supply; otherwise, fruit mass, diameter and fruit height will decrease, and the yield will frittered away. In the study, the most favourable effect of Nevirol 60 WP was detected under additionally fertilized conditions by the author.

Keywords: N-phenyl-phthalamic acid, Nevirol 60 WP, fertilization, apple, fruit setting, fruit quality

\section{INTRODUCTION}

Ensuring yield-balance - although the applied technologies give a good possibility for this - in large-scale farming is a difficult and complicated task (Nyéki et al., 2002). Pollination of certain horticultural species - because of climatic and genetic influences - is not possible in many cases (Kozma et al., 2003; Nyéki and Soltész, 1996). For sufficient yield amount and required yield quality we have to interfere in pollination. With the help of $\mathrm{N}$ phenyl-phthalamic acid, which is an agent of Nevirol 60 WP, we can achieve this goal (Búza, 1986; Racskó, 2002).

The N-phenil-phthalamic acid is a regulator that increases the working life of stigma and supports the better pollination, which results in a higher yield (Nyéki, 2002). The acid is not auxin, but it has a synergistic effect with auxin in biological tests (Nyéki, 1980). This has not caused any phytotoxicity or parthenocarpia (Nyéki, 1980). Applying Nevirol $60 \mathrm{WP}$, the possible unfavourable effects of the objective (agronomics, agrotechnics, species, weather) and subjective conditions of production can be reduced, and yield fluctuation can be levelled, thus, crop safety can be considerably increased. The product, like other regulators and all synthetic pesticides, is not approved in the organic production system (Holb and Heijne, 2001; Holb, 2002b; Holb et al., 2003).
Its application is recommended for the flowering period in greenhouses, and foilhouses, as well as in field (orchard) cultivation for some crops (tomato, paprika, pea, bean, cucumber, grape, apple, sour cherry, lupin, soya) (Eöri, 1984; Teleky, 1985; Teleky and Bésán, 1986; Teleky and Eőri, 1984; Teleky and Horváth, 1986; Teleky and Veress, 1986; Racskó and Lakatos, 2003).

The product may be mixed with insecticides, fungicides and foliar fertilizers, excepting alkaline products. Attention has to be paid to the phytotoxic effect of some scab fungicides in the full bloom period, which should be avoided (Holb, 2002a). The preparation of the spray liquid does not need any special measures, as the praparation contains the necessary constituents to ensure quick and thorough wetting. For applications with ground machine use 400-1000 1/ha, at aerial applications 60-80 1/ha.

It is important to note that while a higher yield is aimed at through better fruit setting, a higher level of basic nutrition should be provided (Szirtes, 1984; Racskó and Lakatos, 2003).

\section{MATERIALS AND METHODS}

The research was conducted in the period from 2003-2004, in field experiments involving private growers at Kálmánháza and Nagylapos. The experimental apple plantations and the various characteristics of cultivars are presented in Table 1. We have chosen seven apple cultivars for the research. Trees were planted in north-south row direction. In our research, the usual cultivation and integrated plant protection was applied.

For better fruit setting, we applied N-phenylphthalamic acid, which is an agent of Nevirol $60 \mathrm{WP}$ in $0.4 \mathrm{~kg} / \mathrm{ha}$ doses. It was sprayed at full bloom. The conditions of spraying application can be seen in Table 2.

For the nutrition supply of the increased number of fruits, we used artificial fertilizer in two doses. We applied it as a base fertilization in solid and granular formulation in January, then as a head fertilization in liquid folar formulation in May. Table 3 demonstrates the conditions of fertilization.

The observation and measurement were carried out on twenty trees per treatment. The total number of trees was 560. Tables contain the average of these data. Trees were assigned at the beginning of research. Each cultivar was represented by four blocks and each block by five trees. Five apple fruits were randomly sampled from each tree for this evaluation, so that the total number was 100 per cultivar. 
Characteristics of the experimental apple plantations and the chosen cultivars

\begin{tabular}{|c|c|c|c|c|c|c|}
\hline $\begin{array}{c}\text { Place of } \\
\text { experiment }\end{array}$ & Cultivar & Rootstock & $\begin{array}{c}\text { Date of plantation } \\
\text { (year) }\end{array}$ & $\begin{array}{l}\text { Size of area } \\
\text { (ha) }\end{array}$ & $\begin{array}{c}\text { Size of parcel } \\
\left(\mathbf{m}^{2}\right)\end{array}$ & $\begin{array}{c}\text { In-row spacing } \\
\text { (m) }\end{array}$ \\
\hline Kálmánháza & Gala Must & MM106 & 1998 & 6.0 & 700 & $4 \times 1.5$ \\
\hline Kálmánháza & Gloster & MM106 & 1998 & 1.8 & 700 & $4 \times 1.5$ \\
\hline Kálmánháza & Granny Smith & MM106 & 1999 & 0.8 & 700 & $3.5 \times 1.5$ \\
\hline Nagylapos & Idared & M4 & 1995 & 4.0 & 400 & $3.5 \times 2$ \\
\hline Kálmánháza & Jonagold & MM106 & 1998 & 3.2 & 700 & $3.5 \times 1.5$ \\
\hline Nagylapos & Jonathan Csány & M4 & 1989 & 2.5 & 400 & $4 \times 2$ \\
\hline Nagylapos & Mutsu & M4 & 1995 & 4.0 & 400 & $3.5 \times 2$ \\
\hline
\end{tabular}

The conditions of spaying application of Nevirol 60 WP (in 2003-2004)

\begin{tabular}{|c|c|c|c|c|c|c|}
\hline \multirow{2}{*}{ Cultivar } & \multicolumn{2}{|c|}{ Date of treatments (day, month) } & \multicolumn{2}{|c|}{ Treatments (x times) } & \multicolumn{2}{|c|}{ Flowering state (\%) } \\
\hline & 2003 & 2004 & 2003 & 2004 & 2003 & 2004 \\
\hline Gala Must & 27 April & 1 May & 1 & 1 & 50 & 55 \\
\hline Gloster & 27 April & 29 April and 2 May & 1 & 2 & 48 & 35 and 70 \\
\hline Granny Smith & 23 and 27 April & 2 May & 2 & 1 & 15 and 60 & 50 \\
\hline Idared & 27 April & 26 April & 1 & 1 & 50 & 48 \\
\hline Jonagold & 28 April & 26 April & 1 & 1 & 50 & 50 \\
\hline Jonathan Csány & 26 April & 26 April & 1 & 1 & 50 & 50 \\
\hline Mutsu & 28 April & 30 April & 1 & 1 & 51 & 52 \\
\hline
\end{tabular}

The conditions of fertilization (in 2003-2004)

\begin{tabular}{|c|c|c|c|c|c|c|c|}
\hline \multirow{3}{*}{ Cultivar } & \multirow{2}{*}{\multicolumn{3}{|c|}{ Fertilization (kg) }} & \multicolumn{4}{|c|}{ Date of fertilization (day, month) } \\
\hline & & & & \multirow{2}{*}{\begin{tabular}{|l|}
2003 \\
base
\end{tabular}} & \multirow{2}{*}{\begin{tabular}{|l}
2004 \\
head
\end{tabular}} & \multirow{2}{*}{\begin{tabular}{|l|}
2003 \\
base \\
\end{tabular}} & \multirow{2}{*}{$\begin{array}{l}2004 \\
\text { head } \\
\end{array}$} \\
\hline & $\mathbf{N}$ & $\mathbf{P}_{2} \mathbf{O}_{5}$ & $\mathbf{K}_{2} \mathbf{O}$ & & & & \\
\hline Gala Must & 80 & 25 & 28 & $22 \mathrm{Jan}$ & 14 May & $20 \mathrm{Jan}$ & 16 May \\
\hline Gloster & 80 & 25 & 28 & 22 Jan & 13 May & $20 \mathrm{Jan}$ & 16 May \\
\hline Granny Smith & 80 & 25 & 28 & 22 Jan & 13 May & $20 \mathrm{Jan}$ & 16 May \\
\hline Idared & 72 & 25 & 25 & 27 Jan & 15 May & 19 Jan & 18 May \\
\hline Jonagold & 80 & 25 & 28 & 22 Jan & 13 May & $20 \mathrm{Jan}$ & 16 May \\
\hline Jonathan Csány & 72 & 25 & 25 & 27 Jan & 15 May & 19 Jan & 18 May \\
\hline Mutsu & 72 & 25 & 25 & 27 Jan & 15 May & 19 Jan & 18 May \\
\hline
\end{tabular}

In our investigations, we determined the following properties of apple:

(1) Fruit setting: This means the number of harvested fruit from 100 flowers per tree.

(2) Number of fruit per tree: This means the number of ripened fruit. The actual value was counted by harvesting.

(3) Fruit weight: The weight of fruit was estimated in 0.1 grams with the help of digital analitic scales.

(4) Fruit diameter: This was measured in 0.1 millimeters with slide-gauge.

(5) Fruit height: This was measured similar to fruit diameter in 0.1 millimeters with slide-gauge.

\section{RESULTS AND DISCUSSION}

Results showed that fruit setting of apple cultivars increased in many cases when N-phenyl-phthalamic acid (Nevirol 60 WP) was applied. The increased nutrient supply could enlarge the fruit setting. This increase of fruit setting was detected for cultivars
Gala Must, Gloster, Idared, Jonagold and Jonathan Csány in 2003 (Figure 1). In 2004, fruit set of cultivars Gala Must, Idared, Jonathan Csány and Mutsu increased with fertilization (Figure 2). However, it is need to mentioned that the increase of fruit setting was not significant in several cases (Table 4).

The positive effect of Nevirol 60 WP on fruit setting was considerable for low setting cultivars (such as Granny Smith in 2003), but it resulted in good fruit setting on cultivar Gala Must too. In 2003, the fruit setting was the highest on cultivar Granny Smith (41.9\%) and in 2004, on cultivars Jonagold $(54.5 \%)$ if Nevirol was applied without fertilization. The fertilization slightly increased the effect of Nevirol 60 WP, and it was significant in 2003 for cultivar Granny Smith (55.6\%) and in 2004 for cultivar Jonagold (54.5\%) (Table 5). Nevirol 60 WP had the lowest on cultivar Gloster in both years and the same results were obtained for fertilization too (Table 5). 
Figure 1: Effect of Nevirol 60 WP and fertilization on fruit setting of apple in 2003

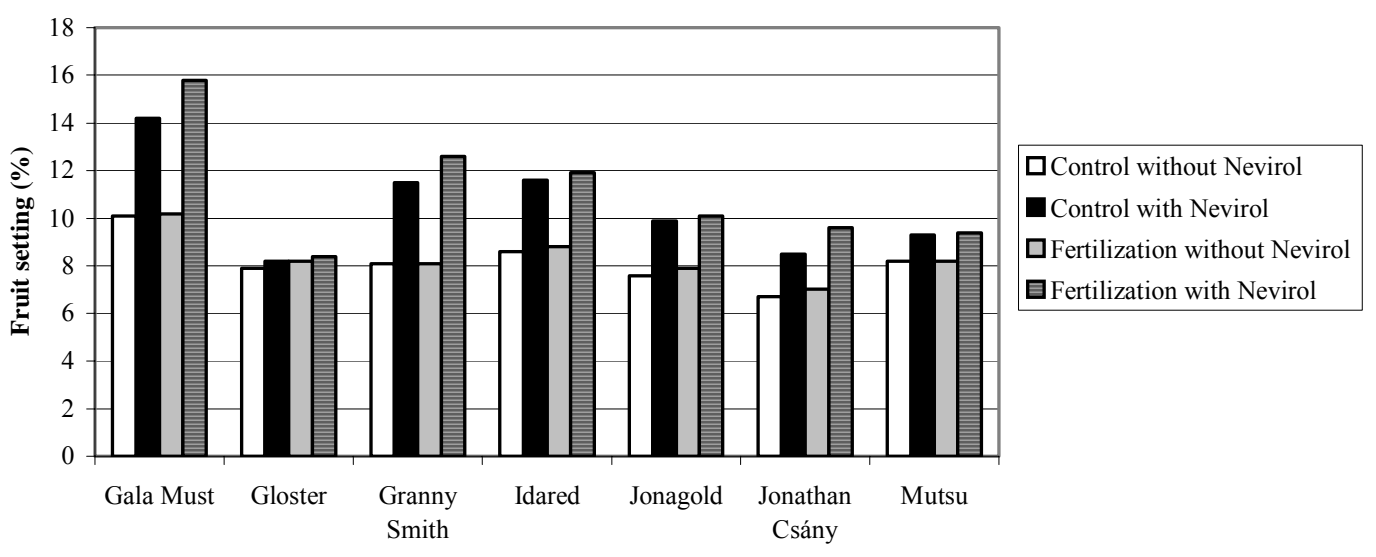

Figure 2: Effect of Nevirol 60 WP and fertilization on fruit setting of apple in 2004

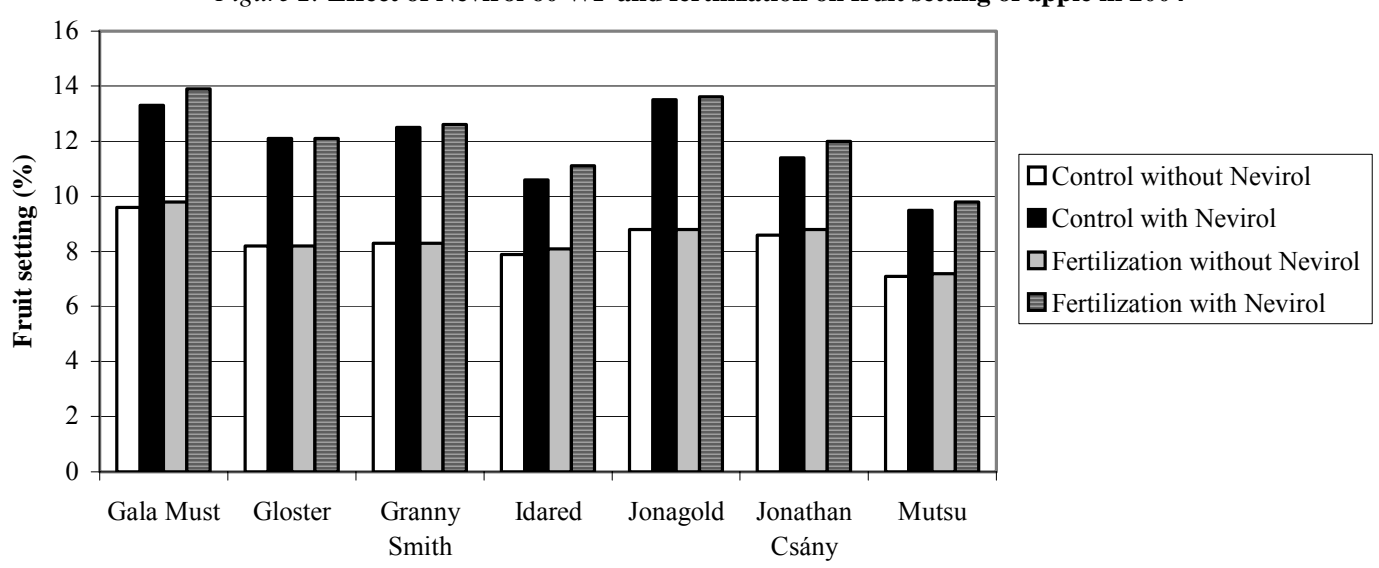

Table 4

Increase of fruit setting (\%) by fertilization in 2003-2004

\begin{tabular}{|l|r|r|r|r|}
\hline \multirow{2}{*}{ Cultivar } & \multicolumn{3}{|c|}{ 2003 } & \multicolumn{2}{c|}{ 2004 } \\
\cline { 2 - 5 } & \multicolumn{1}{|c|}{ without Nevirol } & with Nevirol & without Nevirol & with Nevirol \\
\hline Gala Must & 1.0 & 11.3 & 2.1 & 4.5 \\
\hline Gloster & 3.8 & 2.4 & 0.0 & 0.0 \\
\hline Granny Smith & 0.0 & 9.6 & 0.0 & 0.8 \\
\hline Idared & 2.3 & 2.6 & 2.5 & 0.0 \\
\hline Jonagold & 3.9 & 2.0 & 0.0 & 0.7 \\
\hline Jonathan Csány & 4.5 & 15.3 & 1.4 & 5.3 \\
\hline Mutsu & 0.0 & 1.1 & 0.86 & 3.2 \\
\hline Mean & 2.21 & 6.33 & 1.12 & 2.74 \\
\hline Std. Deviation & 1.91 & 5.65 & 2.20 \\
\hline
\end{tabular}

The measure of increase of fruit setting (\%) by Nevirol 60 WP (in 2003-2004)

\begin{tabular}{|c|c|c|c|c|}
\hline \multirow{2}{*}{ Cultivar } & \multicolumn{2}{|c|}{2003} & \multicolumn{2}{|c|}{2004} \\
\hline & control & fertilized & control & fertilized \\
\hline Gala Must & 40.6 & 54.9 & 38.5 & 41.8 \\
\hline Gloster & 3.8 & 2.4 & 47.6 & 47.6 \\
\hline Granny Smith & 41.9 & 55.6 & 50.6 & 50.0 \\
\hline Idared & 34.9 & 35.2 & 34.2 & 37.0 \\
\hline Jonagold & 30.3 & 27.8 & 53.4 & 54.5 \\
\hline Jonathan Csány & 26.9 & 37.1 & 32.6 & 36.4 \\
\hline Mutsu & 13.4 & 14.6 & 33.8 & 36.1 \\
\hline Mean & 27.40 & 32.51 & 41.53 & 43.34 \\
\hline Std. Deviation & 14.16 & 19.63 & 8.78 & 7.42 \\
\hline
\end{tabular}


The increase of fruit setting increased the number of fruit per tree too. Mean fruit number of tree in 2003 and 2004 can be seen in Figure 3. The greatest numbers of fruit were in cultivar Gala Must and it was decreased in the order of cultivars Idared and Jonathan Csány.

Figure 3: Effect of Nevirol 60 WP and fertilization on number of fruit per tree (average of 2003-2004)

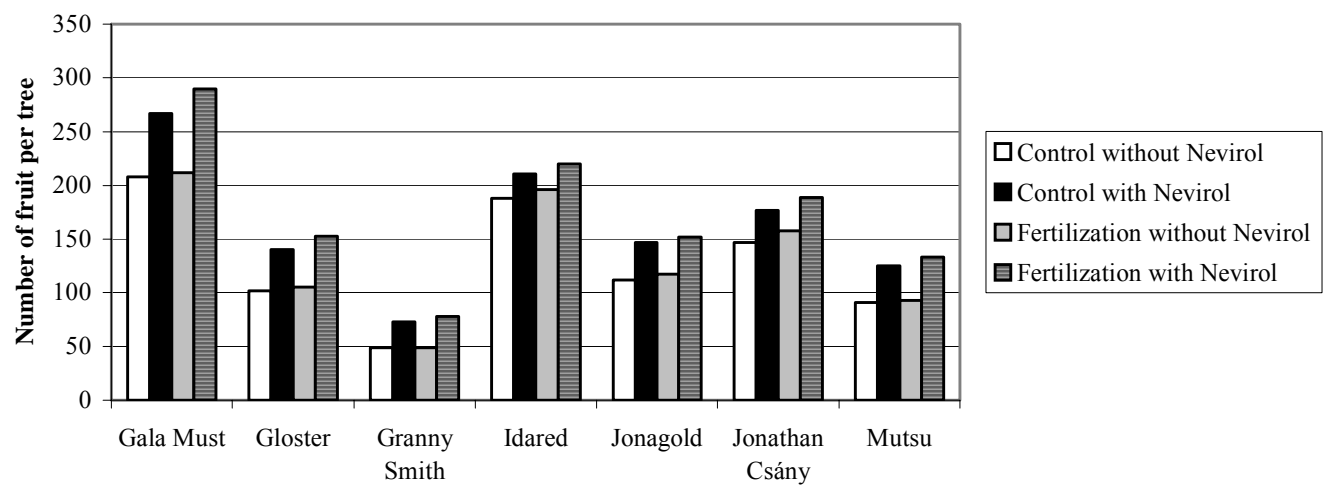

The fertilization increased the fruit numbers per tree, however it was low. The positive effect of fertilization resulted from the lower flower abortion which is can be explained by the increased nutrient content of flowers by the fertilization. The effect of fertilization was the highest on cultivar Jonathan
Csány (16.9 fruits per tree), Gala Must (14.2 fruits per tree) and Idared (7.1 fruits per tree). The low values of fruit number for other cultivars showed that that the number of fruit per tree could be increased by not only with fertilization (Figure 4).

Figure 4: Effect of fertilization on the numbers of fruit per tree (means of 2003 and 2004)

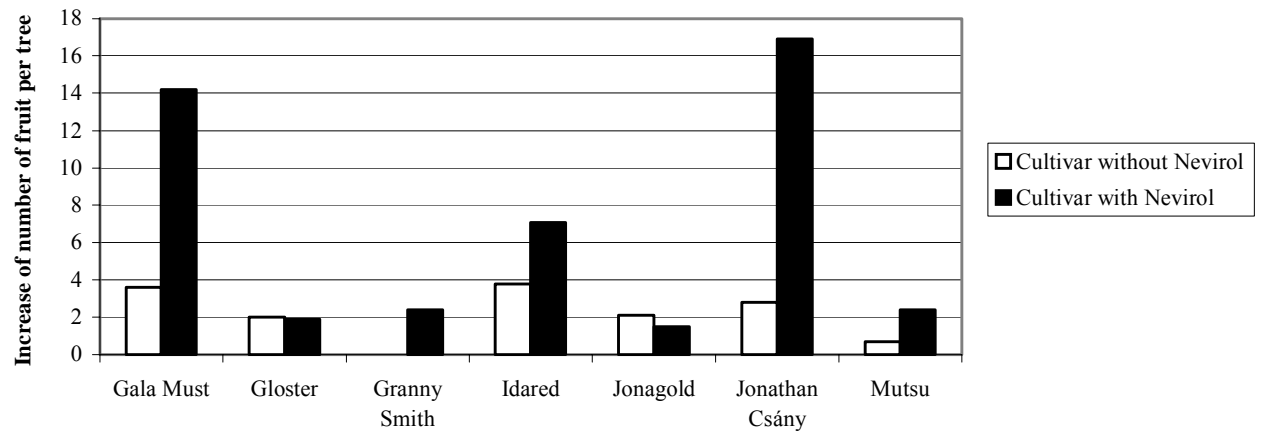

Nevirol 60 WP increased the number of fruit per tree as it was seen for fruit set. The order - without fertilization - was as follows: Gala Must, Idared, Jonagold, Mutsu, Jonathan Csány, Granny Smith and Gloster. The fertilization changed the order as follows: Gala Must, Idared, Jonathan Csány, Jonagold, Mutsu, Granny Smith and Gloster. Higher values of fruit number was observed when fertilization was applied because the fruit abortion was also decreased (Figure 5).

Figure 5: Effect of Nevirol 60 WP on the fruit number per tree

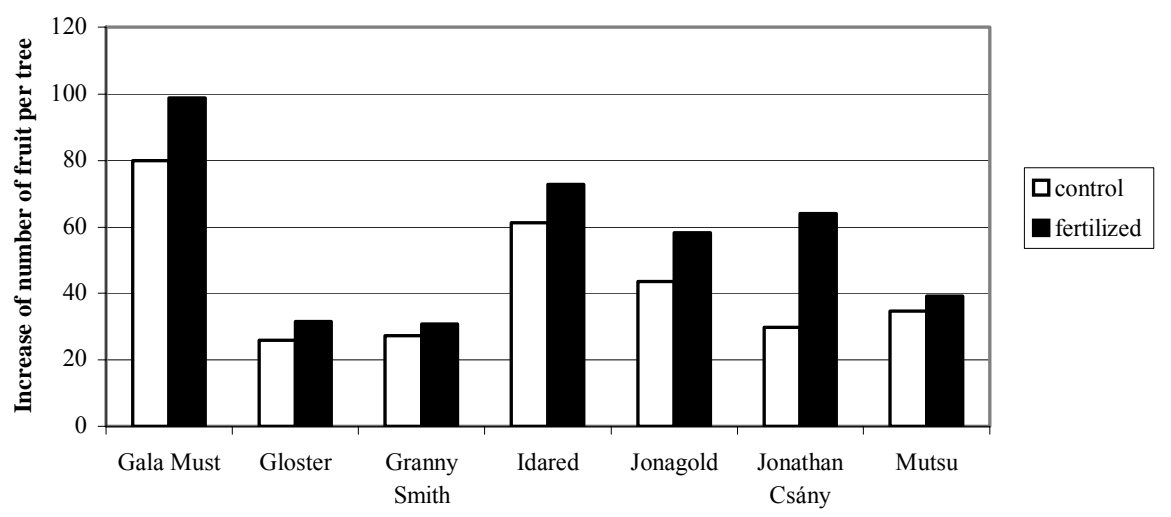


Quality parameters determined by fertilization and fruit number per tree as it can be seen in Table 6 . For example, when Nevirol $60 \mathrm{WP}$ was applied without fertilization the fruit number per tree increased considerably however, it caused a considerable frittering away.

Increase of fruit weight was considerable on all cultivars when fertilization was applied without
Nevirol (Table 6). However, fruit weight decreased when Nevirol 60 WP was applied without fertilization. The reason for this is that fruit set was high and fruit received not enough nutrition for growing up.

Similar tendency was found for the diameter and the height of fruit, but differences among cultivars were little (Table 6).

Effect of Nevirol 60 WP and fertilization on quality parameters of fruit

\begin{tabular}{|c|c|c|c|c|}
\hline \multirow{2}{*}{ Cultivar } & \multicolumn{2}{|c|}{ Control } & \multicolumn{2}{|c|}{ Fertilization } \\
\hline & without Nevirol & with Nevirol & without Nevirol & with Nevirol \\
\hline \multicolumn{5}{|c|}{ Fruit weight (g) } \\
\hline Gala Must & 151.8 & 120.4 & 160.2 & 152.4 \\
\hline Gloster & 169.2 & 146.8 & 194.3 & 170.2 \\
\hline Granny Smith & 146.7 & 131.5 & 159.8 & 147.8 \\
\hline Idared & 154.6 & 144.2 & 176.9 & 153.9 \\
\hline Jonagold & 199.3 & 175.4 & 220.4 & 197.5 \\
\hline Jonathan Csány & 137.8 & 114.8 & 149.8 & 132.8 \\
\hline Mutsu & 146.1 & 126.5 & 166.8 & 145.2 \\
\hline \multicolumn{5}{|c|}{ Fruit diameter (mm) } \\
\hline Gala Must & 70.1 & 63.9 & 73.1 & 70.2 \\
\hline Gloster & 72.2 & 69.1 & 75.4 & 72.6 \\
\hline Granny Smith & 67.5 & 64.8 & 70.0 & 67.9 \\
\hline Idared & 71.8 & 69.5 & 74.2 & 71.8 \\
\hline Jonagold & 76.5 & 73.0 & 80.9 & 75.2 \\
\hline Jonathan Csány & 69.3 & 62.8 & 72.1 & 66.7 \\
\hline Mutsu & 70.9 & 65.5 & 74.4 & 69.6 \\
\hline \multicolumn{5}{|c|}{ Fruit height (mm) } \\
\hline Gala Must & 61.7 & 57.6 & 62.9 & 61.9 \\
\hline Gloster & 68.2 & 66.1 & 70.1 & 68.2 \\
\hline Granny Smith & 65.1 & 62.3 & 67.2 & 65.2 \\
\hline Idared & 64.2 & 62.0 & 65.4 & 65.8 \\
\hline Jonagold & 66.8 & 65.6 & 69.0 & 68.7 \\
\hline Jonathan Csány & 58.9 & 54.9 & 60.4 & 57.0 \\
\hline Mutsu & 60.4 & 57.1 & 62.5 & 60.3 \\
\hline
\end{tabular}

\section{CONCLUSION}

Results show that Nevirol 60 WP and fertilization could increase fruit setting and the fruit number per tree, which resulted in a yield increase too.

Nevirol 60 WP had a great effect on crop yield, especially when Nevirol 60 WP was applied with fertilizer. Both treatments (Nevirol $60 \mathrm{WP}$ and fertilization) showed significant differencess among cultivars. Before using Nevirol $60 \mathrm{WP}$ we have to take into consideration that the increased yield needs higher nutrient supply, otherwise fruit mass, diameter and fruit height will decrease, and the yield will frittered away.

\section{REFERENCES}

Búza, J. (1986): A Nevirol 20 WP alkalmazásának tapasztalatai a szőlőtermesztésben. Növényvédelem, 22. 5. 232-234.

Eőri, T. (1984): A Nevirol, mint regulátor a repcében. Magyar Mezőgazdaság, 39. 20. 9.

Holb, I. (2002a): Az alma ventúriás varasodása: biológia, előrejelzés és védekezés. Szaktudás Kiadó Ház, Budapest, 144.

Holb, I. J. (2002b): Rézpótló készítmények hatékonysága és fitotoxicitása ökológiai alma- és körtetermesztésben. In: Kövics, Gy. (szerk.): A Solanaceae növénycsalád fontosabb fajainak (burgonya, paradicsom, paprika, dohány) időszerű növényvédelmi kérdései. DE ATC MTK, Debrecen, 128-134.
Holb, I. J.-de Jong, P. F.-Heijne, B. (2003): Efficacy and phytotoxicity of lime sulphur in organic apple production. Annals of Applied Biology, 142. 2. 225-233.

Holb, I. J.-Heijne, B. (2001): Evaluating primary scab control in organic apple production. Gartenbauwissenschaft - The European Journal for Horticultural Science, 66. 5. 254-261.

Kozma, P.-Nyéki, J.-Soltész, M.-Szabó, Z. (edit.) (2003): Floral biology, pollination and fertilisation in temperate zone fruit species and grape. Akadémiai Kiadó, Budapest, 621.

Nyéki, J. (1980): Gyümölcsfajták virágzásbiológiája és termékenyülése. Mezőgazdasági Kiadó, Budapest, 334.

Nyéki, J. (2002): Gyümölcstermő növények virágzása és 
termékenyülése, ültetvények fajtatársítása. Egyetemi jegyzet, Debrecen, 68.

Nyéki, J.-Soltész, M. (edit.) (1996): Floral biology of temperate zone fruit trees and small fruits. Akadémiai Kiadó, Budapest, 377.

Nyéki, J.-Soltész, M.-Szabó, Z. (2002): Fajtatársítás a gyümölcsültetvényekben. Mezőgazda Kiadó, Budapest, 382.

Racskó, J. (2002): Növekedésszabályozó készítmények. Értékálló Aranykorona, 2. 2. 14-15.

Racskó, J.-Lakatos, L. (2003): Effect of N-phenyl-phtalanic acid (NEVIROL $60 \mathrm{WP}$ ) on quantitative and qualitative parameters of some horticultural plants. $3^{\text {rd }}$ International Plant Protection Symposium, Debrecen, Proceedings, 216-224.

Soltész, M. (eds.) (1997): Integrált gyümölcstermesztés. Mezőgazda Kiadó, Budapest, 843.

Szirtes, V. (1984): Hormonális szabályozás, levéltrágyázás I-II. Mezögazdasági Kiadó, Budapest, 355.

Teleky, A. (1984): Almafajták kötődésének fokozása Nevirolkészítményekkel. Neviki Közleményei, 15. 93-96.
Teleky, A. (1985): A repce hozamnövelése Nevirolkészítményekkel. Neviki Közleményei, 16. 39-47.

Teleky, A.-Bésán, J. (1986): A Nevirol 60 WP terméskötödést fokozó készítmény a mezőgazdaság szolgálatában. A Magyar Mezőgazdaság Kemizálása '86. XVI. Konferencia Kiadvány, Nehézvegyipari Kutató Intézet, Veszprém, 263-269.

Teleky, A.-Eőri, T. (1984): Nevirol-készítmények a repcetermesztésben. A Magyar Mezőgazdaság Kemizálása '84. XIV. Konferencia Kiadvány, Nehézvegyipari Kutató Intézet, Veszprém, 189-192.

Teleky, A.-Horváth, Z. (1986): Nevirol-készítmények hatásvizsgálata a bácsalmási napraforgó-termelési rendszerben. A Magyar Mezőgazdaság Kemizálása '87. XVII. Konferencia Kiadvány, Nehézvegyipari Kutató Intézet, Veszprém, 266-270.

Teleky, A.-Veress, Z. (1986): Nevirol-készítmények hatása a csillagfürt hozamának alakulására. A Magyar Mezőgazdaság Kemizálása '87. XVII. Konferencia Kiadvány, Nehézvegyipari Kutató Intézet, Veszprém, 277-281. 